\section{Growth of private funding}

SIR - I should like to respond to the five responses to my letter (Nature 350, $370 ; 1991)$ that you have published.

D. H. Roberts, the provost of University College London (UCL), complains of inadequate government funding for science (Nature 350, 550; 1991). But, from the window of his own office, he can see the site for Easai's new UCL research institute. This institute, which will enjoy academic freedom, will also enjoy $£ 50$ million from the private sector. This illustrates my point exactly: British science is growing, but its growth is privately funded.

Frank Ashall and Alison M. Goate (Nature 350, 550; 1991) publish a graph showing that, over the past five years, authors in Britain have published as many papers in Nature as those in Germany, France and Japan combined. Why is this a source of complaint?

Peter Collins, with characteristic courtesy, makes two points (Nature 351, 9, 1991). First, he claims that the increase in the journal coverage by the Institute for Scientific Information (ISI) between 1973 and 1982 reflects the judgements of ISI, and not necessarily the growth of science. Yet the bibliometric and citation criteria that ISI employs makes it clear that its judgements are largely determined by the growth of science (E. Garfield, Current Contents, 28 May 1990, 5-13). Second, Collins is worried that so many short-term academic staff are of technical, not scientific, status. Yet surveys by the Science and Engineering Research Council (SERC) show that Britain enjoys a respectable number of principal investigators. Our major manpower shortfall lies in technical and support staff (Research in the UK, France and West Germany: A comparison, SERC, 1990). Fortunately, the free market is providing them.

Colin Humphreys (Nature 351, 513; 1991) claims that I "argue that British science is growing, relative to the other major industrialized countries". This is not so. I argue that British science is growing absolutely (the facts are undeniable). However, British science grows less quickly than that of other industrialized nations because, unfortunately, Britain's economy grows so slowly (A. Maddison, Phases of Capitalist Development, OUP, 1982). Since international comparisons show that the major determinant of science funding appears to be gross domestic product (GDP) per capita (B. R. Williams, Minerva 3, 57-71; 1964) it follows that our science will experience relative decline (T. Kealey, Scientometrics 20, 369-394; 1991). But relative decline is not absolute decline. We grow.
John Mulvey (Nature 351, 513; 1991) complains that Britain spends too little on science as a percentage of GDP. But it has long been known that the percentage of GDP spent on research and development increases with wealth (B. R. Williams, Minerva 3, 57-71; 1964). Japan and Switzerland spend nearly 3 per cent (almost all of it privately funded), Malawi less than 0.03 per cent and Britain somewhere in the middle as befits our economic status. Mulvey's second point on our lack of industrial preparedness in 1914 is economically incorrect. In 1914 we were 25 per cent richer than Germany in terms of GDP per capita (P. Bairoch, J Eur. Econ. Hist. 5, 273-340; 1976) and 27 per cent more industrialized (P. Bairoch, J. Eur. Econ. Hist. 11, 269-333; 1982). Undeniably, we were unprepared in 1914 in certain areas (notably khaki dye for military uniforms) but that followed on our relatively small expenditure on defence before 1914. Is Mulvey now arguing for more defence expenditure?

University of Cambridge,

Department of Clinical Biochemistry, Addenbrooke's Hospital,

Hills Road, Cambridge CB2 2QR, UK

\section{Animal rights}

SIR - You claim (Nature, 351, 517; 1991) that whereas the arguments propounded by the animal rights movement "go for the heart", those of the biomedical community "go for the head". A sociologist might suspect that the vital organ for vivisectionists is in fact the wallet. (No other members of the scientific community are nearly as incensed by the animal rights movement as those whose careers it threatens.) In any case, it is easy to demonstrate that under their pretence of intellectual objectivity, vivisectionists actually rely on nothing more rational than the age-old appeal of prejudice, of love of one's own kind.

Any vivisectionist would react with horror to the idea of experimenting on brain-damaged humans, or on human infants. Yet chimpanzees are fair game. This simple observation shows that vivisectionists are not primarily concerned with quality of mental function in deciding whether or not to slice up a given organism. There is no room to go into detail here, but such arguments-byobservation can be used to exclude all phenotypic characteristics as essentially irrelevant to the vivisectionist. For vivisectionists, the primary determinant of the moral rights of an organism appears to be whether or not the organism has human DNA. No characteristic of the genome's phenotypic expression is considered nearly as important as the genome itself.

Vivisectionists apparently view this reverence for human DNA as axiomatic, in the sense that it is never justified as the conclusion of a line of reasoning but is rather assumed a priori. Surely even apologists for the biomedical community can see that such a morality has no more to do with "dry, reasoned discourse" than a morality valuing Caucasian DNA over non-Caucasian DNA, or a morality valuing male DNA over female DNA. The difference between vivisectionists and racial bigots is a matter of degree, not kind. Vivisectionist simply draw their lines in the sand at a further remove from themselves than racial bigots do. You do your readers a disservice by claiming that such arbitrary linedrawing reflects some sort of "intellectual rigour".

Theoretical Division and Center

for Non-Linear Studies, LANL, Los Alamos, New Mexico 87545, USA

\section{Bad taste}

SIR - John Parks' letter (Nature 351, $434 ; 1991)$ regretting the fashion-driven perpetuation of methodological errors in animal feeding experiments reminds us of similar errors in diabetes research.

Tissue alterations reminiscent of those found in the complications of diabetes can be produced in many animals by the feeding of a diet consisting of 10 to 25 per cent galactose. Experimental drugs designed to mitigate the pathological consequences of galactosaemia are then added as dietary supplements. However, a common (but rarely observed and much less reported) effect is that the drugs taste noxious, so the animals feed less, consume less glactose and are thus "protected" against tissue damage relative to the control groups (see, for example, A. C. S. Woollard, Z. A. Bascal, G. R. Armstrong \& S. P. Wolff, Diabetes 39, 1347-1352; 1990).

Unscheduled dietary restriction also causes unrecognized reduction of plasma glucose levels in true experimental diabetes and is similarly notorious in the examination of dietary supplements supposed to inhibit age-related pathology. It is not necessarily the case that Kantor's law of the perpetuation of ignorance is the problem. Rather, feeding experiments look simple but are so complex in design, execution and interpretation that they are rarely of value.

SIMON P. WOLFF

ALISON C. S. WOOLLARD

Department of Clinical Pharmacology,

UCMSM, University College London,

5 University Street

London WC1E 6JJ. UK 